\title{
Public Discourse with Advertising Function ${ }^{1}$
}

\begin{abstract}
Our concern in this paper is to analyse public discourse from the point of view of "functional perspective" on speech in Eugenio Coseriu's sense, considering language as a phenomenon that must be explained in finalistic terms. With its distinction of three functional levels of language (universal, historical and individual) and departing from the knowledge of the speaker and the activity of speech, Coseriu's framework offers very adequate instruments for understanding what we can generally call public discourse (as well as other types of discourse). The aim of the present work is to show how we can describe the finality of a text taking into account different types of textual functions involved within discourse. We will focus on political and advertising discourses, two of the most dominant types within public discourse nowadays, and we will concentrate on examples from Romanian.
\end{abstract}

Keywords: finality, functional perspective, advertising and political discourse, integral linguistics.

\begin{abstract}
Rezumat
Lucrarea de față are în vedere analiza discursului public din „perspectivă funcţională” asupra limbajului, în accepția lui Eugeniu Coseriu, care consideră că acesta este un fenomen ce trebuie explicat din punct de vedere finalist. Operând o distincție fundamentală între nivelurile limbajului și pornind de la cunoașterea vorbitorului și activitatea de vorbire, lingvistica de sorginte coseriană oferă instrumente adecvate pentru înțelegerea a ceea ce putem numi discurs public (dar și pentru alte tipuri de discurs). Scopul acestei lucrări este acela de a arăta cum putem descrie finalitatea unui text luând în considerare diferite tipuri de funcții textuale presente în discurs. Atenția noastră se va îndrepta asupra discursului politic și publicitar, două dintre tipurile dominante în cadrul discursului public actual, oferind exemple din limba română.
\end{abstract}

Cuvinte cheie: finalitate, perspectivă funcțională, discurs publicitar și politic, lingvistica integral.

\section{The Coserian functional approach on speech}

1.1. Since the early 50's, Eugenio Coseriu endeavoured to prove that there is no causal explanation for the linguistic change, in opposition to the phenomena described by the natural sciences, because languages do not belong to a causal order, but to a finalistic one, that is to

* Adriana Maria Robu (born 1980) is a Ph.D in Philology ("Alexandru Ioan Cuza” University of Iassy, Romania), whose main research fields are integral linguistics and pragmatics. Her Ph.D thesis, entitled Pragmatic features of the nowadays Romanian advertising discourse shows that the coserian text linguistics instruments are very useful for a pragmatic approach of the discourse, as they facilitate a good understanding of the sense and of the finality of texts. The published articles of the author concern applications on practical efficacy types of texts as political and advertising ones, but also on religious texts. Some of her recent articles: The usefulness of the integral text linguistics concepts for pragmatics (2013), The functionality of the argumentative structures in advertising discourse (2013), Discourse/text from the integral text linguistics perspective (2012), Expressions of the metalinguistic functions of language in religious catholic discourse. A pragma linguistic approach (2012).

E-mail: adriana_robu@yahoo.com

1 This work was supported by the European Social Fund in Romania, under the responsibility of the Managing Authority for the Sectorial Operational Programme for Human Resources Development 20072013 [grant POSDRU/CPP 107/DMI 1.5/S/78342]. 
the category of facts which are determined by their function (Coșeriu 1997: 27). Based on a solid philosophical foundation, Coseriu's conception of language departs, against a simplistic view on causality as such, from Aristotle's distinction between four different kinds of causes ${ }^{2}$ : "effective cause" (the agent or the action used in building something), "material cause" (the material involved), "formal cause" (the plan) and "final cause" (the purpose) (op. cit., p. 176). The meaning of "cause" in the aristotelian sense is not the colloquial one, but it stands for the conditions or circumstances in which something happens. In this context, the most important cause is the "final" one, which subordinates the other three. For instance, the "effective cause" of linguistic change is linguistic freedom, but the universal reason is the communicative purpose of the speakers. It shows that, in language, the speaker makes use of different expressive means so as to achieve a certain goal, namely to communicate something. This is why the linguist should not ask why linguistic changes happen, but to find out how they happen. ${ }^{3}$

1.2. The coserian outlook, anti-positivistic in its essence, conceives integral linguistics as a science of culture, which deals with the functional levels of speech. It is related to the essential universals of speech (semanticity, alterity, creativity) ${ }^{4}$, starting from the knowledge of the speaker and from the activity of speech. Thus, an objective theory of speech will take into account that speech is a general human activity usually performed individually on the basis of a historical linguistic technique. This creative activity of speech is analysed at three levels (universal, historical and individual), which involve three specific techniques (elocutional, idiomatic and expressive competence), as we can see in Table 1.

\begin{tabular}{|l|l|l|l|}
\hline $\begin{array}{l}\text { Points of view } \\
\text { Levels }\end{array}$ & $\begin{array}{l}\text { enérgeia } \\
\text { Activity }\end{array}$ & $\begin{array}{l}\text { dýnamis } \\
\text { Knowledge }\end{array}$ & $\begin{array}{l}\text { érgon } \\
\text { Product }\end{array}$ \\
\hline Universal & Speaking in general & Elocutional knowledge & Totality of utterances \\
\hline Historical & $\begin{array}{l}\text { Concrete particular } \\
\text { language }\end{array}$ & Idiomatic knowledge & $\begin{array}{l}\text { (Abstracted particular } \\
\text { language) }\end{array}$ \\
\hline Individual & Discourse & Expressive knowledge & Text \\
\hline
\end{tabular}

Table 1. Levels of speech (Coseriu 1985: XXIX)

2 For the question of causality and finality in linguistics, see also the discussion forum in this issue of Energeia.

3 As we can notice, the coserian functional perspective differs from other tendencies in language studies which use the term "functional" with diverging meanings. For instance, in structural linguistics it refers to the relations between different structural elements, while a functional perspective in present-day pragmatics means: "an approach to language which takes into account the full complexity of its cognitive, social, and cultural (i.e., 'meaningful') functioning in the lives of human beings" (Verschueren, Ösman eds. 2009: 19). This again is opposed to social sciences which understand the functionalist relations as functions between structural categories. The functionalist pragmatic approach emphasizes on interpretation and meaning, dealing with three main properties of language: variability, negociability and adaptability (op. cit., p. 1922). For other details concerning the "functional explanation" see Esa Itkonen's article in this issue.

4 E. Coşeriu, Universaliile limbajului şi universaliile lingvisticii, in E. Coşeriu 2009: 78-80. 
The investigation of discourse/text, from the perspective of integral linguistics, starts from the premise that, within discourse, linguistic knowledge (including metalanguage, diachrony, repeated discourse, diatopic, diaphasic and diastratic variation of the historical language) and extra-linguistic knowledge (knowledge of things in general) are involved, both representing sources of sense construction. In other words, in terms of discursive activity, integral text linguistics does not analyse the text according to external factors, but it focuses on the possibilities of the meaning, conferred by the signifying function of the language (logos semantikós). Semanticity is a constant feature of language, which, within discourse, is determined by internal finalities.

1.3. The functional levels of speech were fruitfully discussed by Óscar Loureda Lamas with respect to text linguistics. Taking into account the three types of text linguistics from Coseriu's framework (general theory of text, text grammar or transphrastic grammar and text hermeneutics) Loureda refers to this as "threefold text linguistics":

Coseriu denomina al análisis del texto como nivel último del hablar lingüística del texto o lingüística del sentido. Pero esta lingüística del texto es, en realidad, "tres veces lingüística del texto". Los textos son hechos individuales, pero no absolutamente singulares, pues presentan, además, una dimensión universal, que incluye aquellos rasgos de la textualidad, y una dimensión histórica que hace que compartan tradiciones y moldes expresivos; dicho de otro modo, la lingüística del texto debe explicar, primero, qué es un texto en general y cómo se configura, de modo que en este sentido se trata de una teoría general del texto; segundo, debe explicar qué rasgos comparten distintos textos y qué función tienen en el hablar, de modo que se trataría de una lingüística de la dimensión tradicional del hablar; y tercero, debe explicar qué significa, en toda la extensión de la palabra, tal o cual texto en tal o cual situación, es decir, debe ser una hermenéutica de los textos o filología (Loureda 2007).

The same linguist operates a systematization of the discourse analysis modalities, starting from the coserian text linguistics model, which includes the real and functional dimensions of the text. As far as pragmatics (in a cognitive approach) is concerned, it views the universal level of speech, but text grammar and systematic functional linguistics analyse the idiomatic level. Within the individual level, the discourse study disciplines are placed as follows: pragmatics, enunciation theory and argumentation theory refer to the universal dimension of the speech; textual typology, repeated discourse and discourse tradition belong to the traditional dimension; and stylistics of speech, critical analysis of discourse, textual semantics and hermeneutics analyse the individual dimension. 


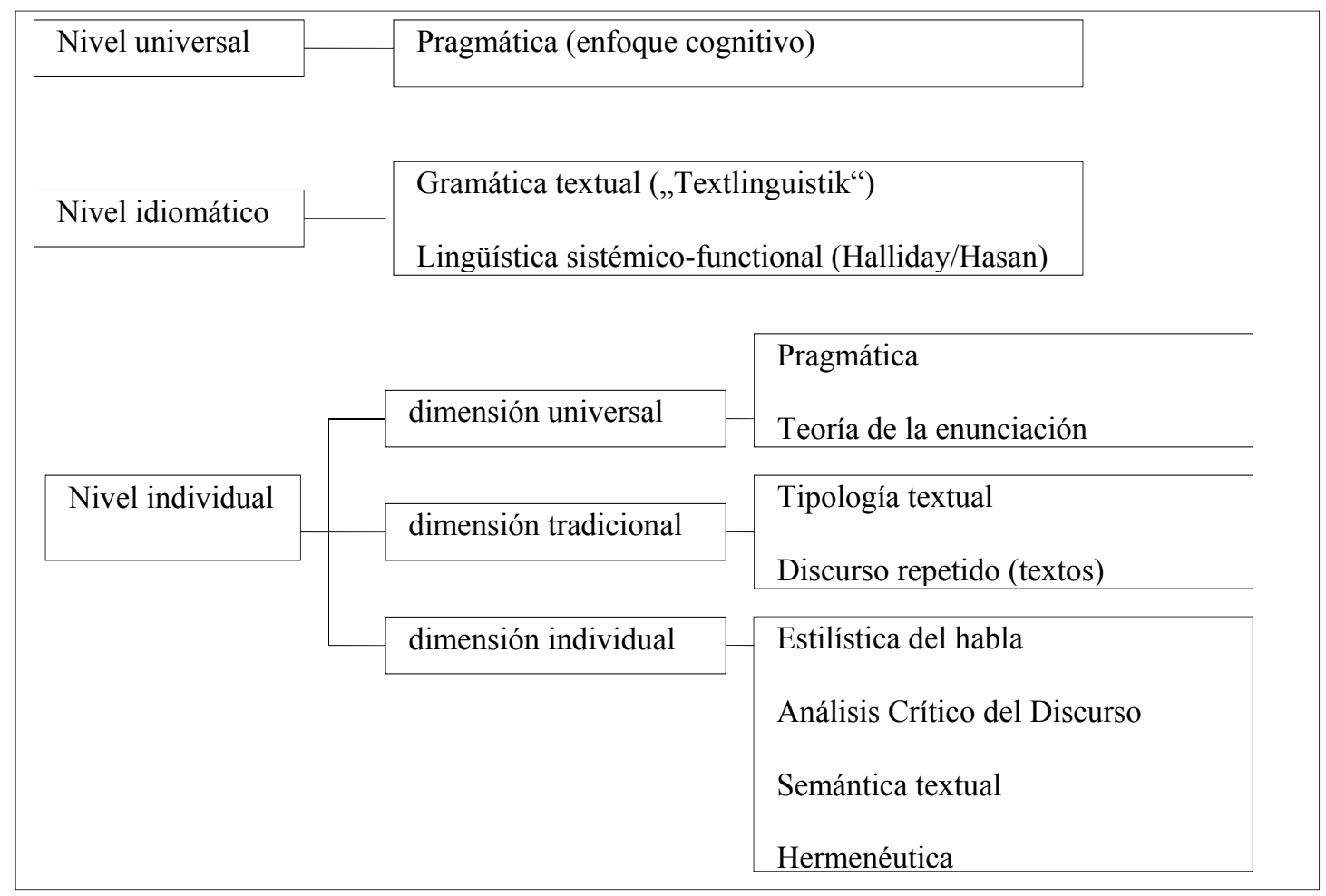

Table 2. La lingüística del hablar (Loureda 2010: 151)

This coserian distinction of speech levels allows diversifying the possibilities of the research and shows a better understanding of language essence and of its reality. The coserian model was extremely profitable applied in different fields by many researchers, who even continued Coseriu's work. In a very incomplete enumeration, we can mention some of them: Heidi Aschenberg (1998) with regard to translation theory, Wulf Oesterreicher (1997), Peter Koch (1997), Johannes Kabatek (2005) in discourse tradition, Mircea Borcilă (2008) in the matter of stylistics, Óscar Loureda Lamas (2010) in the field of textlinguistics, Emma Tămâianu (2001) in textual typology sphere etc.

1.4. The aforementioned finalistic view of integral linguistics offers a very useful view on text typology. According to the same Aristotelian tradition, it assumes the following discursive finalities: the scientific finality (logos apophantikós), the pragmatic finality (logos pragmatikós) and the poetic finality (logos poietikós) (Coșeriu 2011:125). Each of these finalities reveals the speaker's attitude, intention and the relationship with the interlocutor, considered as internal relationships of it with its own speech. Thus, Emma Tămâianu (2001: 195) states that "text typological organization can only be defined as the modality of sense construction - i.e. the modality to which the significata and designata of text units constitute a second degree signifier -, and the modality of the internal sense-articulation (Gliederung des Sinns)". The same author considers that classical text typologies based on traditions of texts are not able to give information concerning their sense, because the text/discourse is not an activity limited to patterns. That is why even a typological approach to texts should refer to their internal sense which builds up by means of a variety of devices (see infra 3). 


\section{What is public discourse?}

2.1. First, we have to say that the concept of discourse is usually opposed to that of text in different structural, positivistic and pragmatic orientations, which are, in their turn, opposed to the meaning the concepts have in integral text linguistics. Current research in Pragmatics places discourse in general and particularly public discourse at the crossroads of linguistics with psychology, sociology, ethnomethodology or theory of communication. Consequently, the concept has now a series of complementary and even contradictory definitions. Generally, discourse is considered a linguistic activity, a way of using language. If structuralism stopped at the level of the sentence, discourse analysis takes into account social, cultural, situational factors which offer it a more ample understanding. For instance, in Anne Reboul's and J. Moeschler's opinion (1995: 246), discourse is not a naturally pertinent category from scientific point of view and, consequently, it does not require a special treatment. They consider that a pertinent category which deserves attention is utterance. Generally, discourse analysts see discourse as being anchored in a certain socio-cultural context, orientated by a certain finality which is determined by the roles of the discursive agents; while text appears as a series of sentences with semantic features.

2.2. According to Eugenio Coseriu, discourse and text are seen as complementary aspects of the speech. Thus discourse is:

Language as activity, which [...] must be understood as "speaking and understanding" [...]. It is in the proper sense enérgeia, actus, that is a creative activity, which makes use of dýnamis, an already acquired Knowledge, in order, however, always to say something new, something in one way or another unique; and to the extent to which it is creative, inasmuch as it manifests "facts of speech" in the narrower sense, it goes beyond its own dýnamis and produces new, virtual knowledge, facts which can be taken over in the dýnamis, for further speech acts. Moreover, as it is a question of a productive activity, we can also regard it in terms of its products, that is as érgon (1985, pag. XXVII).

And this érgon can be observed directly in texts:

A text is nothing but the product of a speech act or of a sequence of speech acts, or, rather: these speech acts themselves as a product, which can be either retained in memory or recorded and preserved in a material, in taped, written, or printed form. It is therefore fitting to begin by distinguishing between language kat'enérgeian (speaking and understanding), language katà dýnamin, and language kat'érgon (loc. cit.).

Coseriu also adds that these two concepts are not opposed, but they "constitute only different points of view concerning the same real phenomenon". We think that, when we analyse an aspect of speech, even if we depart from the discourse (implying verbal and nonverbal elements), or if we depart from the text (related to the enunciation context), the main reference is language. That is why these two concepts should not be separated. ${ }^{5}$ We can also notice that some aspects of the coserian theory about text/discourse sometimes meet theories from linguistic pragmatics but they are placed by Coseriu in a larger framework of analysis, as early as the 50's (in Determinación y entorno [1955-1956] and then in Textlinguistik [1980]).

For a synthesis concerning the coserian text/discourse distinction and other orientations in the matter, see Robu 2011a. 
2.3. In determining the nature of the public discourse and of its subtypes, we will resort to a new classification of the "functional styles" achieved by Stelian Dumistrăcel in Romanian linguistics. Taking into account Karl Bühler's functions of the sign (revised by Coseriu subsequently): denotation, manifestation and appeal ${ }^{6}$ and their correspondence to Aristotle's types of logos (apophantikós, pragmatikós and poietikós), Dumistrăcel (2006a: 43) achieves to an original configuration considering that there are only three "functional styles": fictional style, technical - scientific style and public and private communication style. ${ }^{7}$ The last one, which we are interested in, subordinates two important types of discourse: private and public. In its turn, public discourse has two main subdivisions: mass-media discourse (covering journalistic discourse and advertising discourse) and institutionalised authority discourse (including school instructional discourse, political organisations discourse, legaladministrative discourse and religious discourse) (op. cit., p. 46).

As we can see, all these delimitations are made on extra-linguistic criteria, that is why the types included in public and private communication style can be studied from a general text linguistics perspective, according, for instance, to the "practical efficacy value", as Coseriu (Coseriu, Loureda 2006: 43) emphasized in a study about the political discourse. Within this taxonomy we can even find two very similar types of discourses from the point of view of their finality. Thus, we can say that advertising discourse and political electoral discourse belong to the practical efficacy category of texts, because of a pragmatic subsequent determination nature, i.e, persuasion. This means that the electoral discourse assimilated the language of the advertisements because the goal is also to persuade people, by means of seduction through language.

An argument in sustaining the similarity between political and advertising discourses is that, in supporting persuasion, they use the same argumentative strategies, like: rhetorical question, polemic negation, argumentative metaphor, repetition figures, construction figures and so on. ${ }^{8}$ For instance, if we analyse a political slogan and an advertising one, we cannot see any difference between them from an argumentative-discursive point of view, or we can also notice the frequency of using different forms of repeated discourse so as they can be easily remembered. A relevant example is the electoral slogan of one of Obama's opponents, Mike Huckabee, who, taking over the well-known slogan I Like Ike used

(1) I Like Mike.

We can also remember the masterly slogan used by the Romanian President Traian Băsescu:

(2) Să trăiți bine! (Live well!) ${ }^{9}$

which evokes his name (because of the same initials) and implicitly the idea of well-being that he may bring to people. The slogan has also a shade of sobriety specific to military greetings, hinting at the professional background of the candidate. Another example is the liberal slogan

6 The Romanian linguist also considers Coseriu's critique to R. Jakobson's theory regarding the functions of the sign.

7 This distinction is very close to Coseriu's four universes of discourse (see infra 3.4.5.). The difference is that Coseriu did not talk about functional styles and that the "style of faith" would be a fourth one in his perspective.

8 We can even say that political electoral discourse is a subtype of advertising discourse, because its finality is to sell images, trying to convince people to take action (see Robu 2010).

9 The Romanian examples used in this paper are taken from Robu 2013. The corpus of texts was collected from radio and TV advertising and political discourses during September 2011-April 2013. 
(3) Prin noi înşine! (By ourselves!)

which reveals the essence of the liberal doctrine regarding the belief in the liberal values, namely to promote the idea of common well-being because of the individual initiative. It can be compared with advertising slogans:

(4) Raiffeisen - reușim împreună! (Raiffeisen - We win together!)

(5) Vodafone - împreună suntem mai puternici! (Vodafone - together we are more powerful!)

This is also a good way, for those behind these types of texts, to manifest their power by means of discursive seduction. Beyond the words, language represents a way of manifesting power and capacity of control, and, either at verbal or at non verbal level, it acquires symbolic dimension in these two types of discourses. Referring to the advertising within the political discourse, F. Brune considers that:

It has to concern everyone, from owners to presidents. It has to be simple and elementary. It has to come from the heart. It is a shout, a Vote me, please!, a declaration of love. How would France understand what you mean if you had not the most simple and the most stupid set of arguments? But, behind it, the persuasion and the passion must be felt [...]. There is no difference between a detergent and a president of a republic. Both of them are elected from a simple poster (our trans. Brune 1996: 45).

The French author, in a critical note, concludes that the advertising language perverts the political message, and the leader, who is allured in the dizziness of the advertising communication, discredits his own political sense of action. We consider that this act of adhesion to advertising communication does not mean discrediting. At the most it can be considered a compromise which the politicians equally make to ensure the delivery of their message to the voters in various forms, ranging from the verbal to the gestural, iconic and musical messages, which basically are symbols used persuasively. ${ }^{10}$ Beyond all these facts that show how to understand the features of public discourse in general and the political and advertising ones in particular, we are interested in the means that contribute to the sense construction and consequently to the specific finality of the texts.

\section{How to get to the finality of the public discourse}

3.1. Following the coserian model of discourse/text analysis we will render a way of understanding public discourse by means of the textual functions whose contribution to the sense of the discourse is decisive. The textual functions are defined by Coseriu as "speech functions in a certain situation or functions which refer to a certain goal of the speech" (Coseriu 2007: 149). According to Coseriu, the textual functions do not coincide with sentence functions, because the text is not situated exclusively on the historical level. There are some other reasons to differentiate between the two types of functions: first of all a text may not be necessarily written in one language, secondly, the same sentence in a language can perform different functions (i.e. an interrogative sentence may express both question and doubt or the text might contain categories which do not have an expression form in a given

10 Let's not forget that this critic of Brune's is motivated by the fact that he himself is the leader of a resistance association against the advertising aggressiveness called Résistance à l'Agression Publicitaire. 
language, as it is the case of "objection" or "answering back"), then the texts depend on the universe of the discourse and on the situation in which they are uttered, and also, they belong to certain discursive or textual traditions (Coseriu 2007: 132-139). We can notice here a similarity between the textual function from Coseriu's outlook and John Austin's theory of speech acts. According to Austin, the performative act implies three complementary activities: the fulfilment of a locutionary act (production of a chain of sounds in a certain language), then of an illocutionary act (production of an utterance endowed with a certain strength, invested by the speech act itself) and the performing of a perlocutionary act (which overtakes the actual linguistic frame, in the sense that several effects are revealed in the communication process with the help of speech). ${ }^{11}$ At this illocutionary level we find the coserian textual functions which are dissociated in: implicit textual functions (based on textual presuppositions) such as: rejection, acceptance, allusion, argument, example, reply, statement, irony, opinion etc., and explicit textual functions (which are independent of the presuppositions) such as: instruction, encouragement, information, request, explanation, advice, promise etc. Coseriu considers that a fundamental criterion of typological characterization is the distinction between dialogical textual functions (like question/answer) and non - dialogical textual functions (Coseriu 2007: 330-331), which can lead to further distinctions.

3.2. From the illocutionary dimension perspective of the advertising discourse, textual functions are noticeable by the cooperation between the informative and the argumentative value, which contributes to the info-persuasive character of the advertising communication. Thus, the illocutionary force which distinguishes advertising, but also political discourse, have a captatio benevolentiae role, which means it concentrates on the appeal function of language, by means of an ascertaining communication (signalling a new product, its qualities and the advantages to use it), on the one hand, and of an indirect, implicit communication (regarding the desire to have the product), on the other hand. The most privileged instance in this case is the recipient, because the discourse is made according to the type, preferences and motivations of the consumer.

3.3. From the perspective of textual functions, the advertising discourse stands by means of some features which help to delimit it within the practical texts. Such functions as "insinuation", "deliberated falsification of the things", "hiding the thinking", placed under the power of the practical efficacy, make the receiver unable to check the validity of the message, or make him give it an "innocent" interpretation (Coseriu, Loureda 2006: 41). The result is the manipulation of the receiver of the message, who is persuaded to "take action in a way or another or to take a certain stand" (loc cit.), because he is offered favourable arguments.

Sometimes this is done through a narrative scheme, as an implicit textual function, which helps to give the receiver a sensation of happiness, fulfilment or joy. Considered in its complexity, as text, image and music, advertising discourse hides a message which favours the most wished values like the desire to live, well-being, happiness in association with the material aspect, thus suggesting a wish, a fascinating dream outlined by means of semiotic codes, by intertextual resources and discursive interactions. For example, a spot for mineral water proposes the following narrative scheme:

11 These three acts are called by J.-M. Adam (2008:123): enunciation dimension, argumentative potentiality and illocutionary value. 
(6) Cât a ţinut vrăjmăşia dintre Împăratul Focului şi Regele Gheţurilor? Până când iubirea..., până când, plecat la vânătoare, feciorul Împăratului de Foc luă urma Inorogului fermecat. Prin Pădurea Ielelor, peste Valea Plângerii, până în inima munţilor. Așa cunoscu prinţul pe cea mai frumoasă dintre făpturi - Prinţesa Ghețurilor. Şi iubirea lor, minune, izvor veşnic s-a făcut. Lumea s-a schimbat, dar izvorul încă mai susură... Transformă-te în iubire!

(For how long has the hatred between the Fire Emperor and the King of the Ice lasted? Until love..., until, set to hunting, the Fire Emperor's son, followed the footsteps of the enchanted Unicorn... through the Fairies' Forests, over the Wail Valley, to the innermost of the mountains. This is how the prince met the most beautiful creature - the Princess of the Ice. And their love... through a miracle... became eternal spring. The world has changed, but the spring has been still purling... Change yourself in love!)

This text, written and spoken almost like a poem, bears the receiver in a universe of eternity, governed by love. Here the narrative scheme becomes also a pretext to make us remember the trademark easily.

If we have a look at the political electoral discourse a common textual function is the rhetorical question as in:

(7) După cinci ani de mandat Băsescu, românii trăiesc mai bine? (Do the Romanians live better after five years of Basescu's presidential term?)

This type of rhetorical question assumes a negative argumentative reading, because, using the well-known slogan of the President, the speaker (his opponent in the 2009 elections) criticizes him for causing the political and economical crisis.

The level of textual functions may help us to individualize the advertising discourse from scientific or literary texts and even from other practical ones.

3.4. Apart from these textual functions which can be modelled according to the peculiarity of each text, Coseriu speaks about another category of textual functions called evocative functions. These are discussed from a semiotic perspective, concerning the relations which the linguistic sign establishes within a text/discourse. The evocative semantic functions are the following: relations of the sign to other signs, relations of the sign in a given text with signs from other texts, relations between signs and things, relations between signs and knowledge of the things and the sourrounding fields (entornos) (Coseriu 2007: 181-233). The complexity of these relations of the signs are discussed by Coseriu referring to literary texts, especially because they represent the best scenery of actualizing these functions, but we can easily notice that the public discourse offers good resources of analysing signs' relations.

3.4.1. As far as the relation between signs is concerned, in the advertising text we can find examples, for instance, of multiple meaning words, as in a Romanian bank slogan:

(8) Mulţumim pentru creditul acordat (Thank you for your credit).

In this slogan, the word credit evokes, besides the idea of finance offered by the bank, the idea of 'trust' as well. Or in a slogan for a drug

(9) Aspirin Plus C se ia de răceală (Aspirin Plus C is given to cough) 
the phrase a se lua de cineva (to attack somebody) is used, on the one hand, with its canonical meaning, and, on the other hand, with the meaning "to be taken for colds".

3.4.2. The relations of the signs with signs from other texts distinguish by means of the repeated discourse, which is important not only because of those modifications called quadripartita ratio (from Quintilian), but due to the re-semantisation of canonical forms or because of the overlapping between fixed and free (identical) forms. For instance, as we can see in an advertising spot for chewing gum:

(10) Mesteci şi faci faţă distracţiei. (You chew and you cope with the entertainment.)

It uses the Romanian phrase a face faţă (to cope with) together with displaying the image of some children making funny faces while chewing gum. The Romanian phrase is important in this context because the fixed form a face fată overlaps on the free one connected with the meaning "to change faces". 12

But the most fruitful sources of repeated discourse are the four rhetorical quadripartita ratio: adiectio, immutatio, detractio and transmutatio. ${ }^{13}$ The procedure of changing a canonical form of a phrase, by adding a new word to it and using the initial utterance in a new context which enriches its expresivity, is called adictio (addition). There are many such examples in the public discourse:

(11) V-aţi întâlnit cu tot felul de persoane, aţi plâns şi dumneavoastră public de mila salariilor lor! (You've met all kinds of people, and you've publicly felt pity for their salaries! (political text)

Here to the phrase to feel pity for (somebody) the word salaries is added to show ironically a false compassion of the politicians towards people with law salaries.

(12) Trăieşte fiecare clipă (Live every moment) (advertising text).

This example evokes the Latin proverb Carpe diem. The Romanian advertising slogan makes use of the addition to emphasize the idea of living every important moment of your life, as the advertisement was about a photo camera.

(13) Ca să fii cineva, trebuie să ajungi undeva (To be somebody, you have to get somewhere) (advertising text).

The phrase to be somebody is completed here, through addition, with the idea of the necessity "to get somewhere" by plane, as the advertisement promotes airline services.

Immutatio (substitution), which consists of changing a word of a phrase with a new one, is the most influential device in fixing new phrases in language. In political discourse they are mostly used for ironical reasons, while in advertising their relevance is usually connected with the strategy of keeping the trade mark, because these new forms can be easily remembered.

(14)Fanta la distracţie se cunoaşte (A Fanta in entertainment is a friend indeed) (advertising text).

12 This example is also explained in Munteanu 2007: 198.

13 For a detailed presentation of all these rhetorical devices with an application to the journalistic text, see Dumistrăcel 2006b. 
The advertising slogan evokes the well-known proverb "A friend in need is a friend indeed". The substitutions of the words friend $\rightarrow$ Fanta and need $\rightarrow$ entertainment suggest the benefits of Fanta juice when you want to have fun.

(15)Înainte să modificăm Constituţia după cheful şi asemănarea unui preşedinte, să vedem ce s-a întâmplat cu neaplicarea drepturilor constituţionale ale cetăţenilor acestei ţări (Before we modify the Constitution after a president's mood and resemblance, let's see what happened with misapplication of the constitutional rights of our citizens) (political text).

This example contains two substitutions within the canonical religious phrase "after God's look and resemblance". The word chip (look) is substituted with the word chef (mood), which in Romanian sounds almost identical, and the word president substitutes the word God, resulting an ironical new text suggesting the way a Romanian President changes the Constitution as he wishes.

Detractio (deletion), which makes use of ellipse, and transmutatio (permutation) that consists of changing the word order in a phrase, are rarely used in public discourse as they ask for much more cognitive effort, as compared to the other rhetorical procedures. Still, here is an example of detractio taken from the political discourse:

(16)Domnule Antonescu, săriţi calu'! V-am menajat până acum din motive tactice în această campanie prezidenţială (Mr. A, you jump [over] the horse! I've spared you in this presidential campaign because of tactical reasons (political text).

In this example the deletion concerns the original phrase a sări peste cal (to jump over the horse) where the preposition peste (over) has been deleted.

All these kinds of stylistic devices are used in the public discourse either for ironical or for playful reasons, making the receiver to remember the texts easily and involuntary take a certain stand towards a product or towards a political idea.

3.4.3. If we refer to the relations between signs and things, some words may also evoke different meanings which appeal to certain biological senses like taste, touch, smell, seeing, tactile sensations etc. These kinds of relations are profitably used in advertising. For instance, in an advertising spot for coffee, they will make use of some words like flavour, testiness, the pleasure of taste, or in some spots for cosmetics the most favourite words are delicacy, firmness, freshness etc. Sometimes we can almost feel the coolness and the taste of the beer, wine or that of the natural juice which is promoted. Here an important role can be played by the icastic function, so as to suggest the advertised product. The sign is also directly related to the representation of things, and this can be seen in such texts which use certain graphical signs or sounds to make the reader/hearer to think of something acute, deaf, shining, darkened etc., by means of vowels or consonants. We can also talk about the presence of distinctive signs used in those strategies which concern the trade mark identity, so as to associate the product with certain symbols. The trademark identity can be easily recognised due to semiotic elements like: teddy bear, dolphin, panther, red, green or orange colour for mobile phone companies, to which we can add some trademark signifiers like: facility, quality, applicability, mobility etc.

3.4.4. With reference to knowledge of the things, the signs in public discourse have also intentional value when they hint at some age, social, professional, cultural or ethnic 
categories. The use of politeness pronouns, for instance, is a way to select the receiver. In the advertisements for luxury products politeness pronouns are used especially to suggest the superiority of the client as opposed to others who use casual products. The contribution of knowledge of the things to speaking may be studied, in Coseriu's opinion, by what he called "linguistic skeology" (from gr. skéuos, which means 'thing', 'instrument') (Coseriu 1992: 148-152).

A device used for manifesting the relation between signs and knowledge of the things is, both in advertising and political discourse the hyperbole. From the visual hyperbolization of the waterfalls, which become miraculous mineral waters, of the cars able to transform in huge creatures climbing the most unbelievable places, to extremely various verbal hyperbolization, the exuberant imagination often overcomes reason. For example, the hyperboles from these two slogans:

(17) Dorna te încarcă cu toată puterea (Dorna charges you with all the power).

(18) Natura întâlneşte oraşul (The nature meets the city).

are completed by the image of real, full of energy characters, which metamorphose under the reign of the mineral water, becoming primordial principles which travel hyperbolically through the jungle, the desert and finally arrive into the city.

The hyperbole in the political discourse is usually used to exaggerate a certain state of affairs, like in this example:

(19) $\mathrm{Nu}$ putem ieşi din tensiunea şi aproape nevroza publică în care România s-a cufundat decât printr-o soluţie pe care toate sistemele democratice au aplicat-o şi o aplică în astfel de situaţii: alegeri anticipate.

(We cannot get out of the public pressure and almost the neurosis in which Romania has immersed except by a solution which every democratical systems has been implemented in such situations: beforehand elections).

3.4.5. In order to understand the articulation of sense in certain texts/discourses, so as to get to its finality, it is really profitable to explore the sourrounding fields which the enunciation implies or the level of the circumstances in which speech occurs. The sourrounding fields are those which contribute to the possibility to understand what is beyond language:

Los entornos intervienen necesarmente en todo hablar, pues no hay discurso que no ocurra en una circunstancia, que no tenga un "fondo". Como se ha visto, los entornos participan de manera casi constante en la derterminación de los signos y a menudo sustituyen los determinadores verbales. Pero su functionalidad es mucho más amplia que esto: los entornos orientan todo discurso y le dan sentido, y hasta pueden determinar el nivel de verdad de los enunciados (Coseriu 1955-1966: 45).

With regard to the typology of surrounding fields, Eugeniu Coseriu speaks about some taxonomy from the theory of contexts laid down by Ch. Bally, K. Bühler and W. M. Urban. ${ }^{14}$ But the coserian theory about the surrounding fields is still the largest we have today. There are four ample types of sourrounding fields: situation, region, context and universe of discourse. ${ }^{15}$ Schematically the sourrounding fields typology is the following:

14 To all these we can add more recent results in the theory of contexts from Sperber \& Wilson's Relevance Theory (1983), that of Teun Van Dijk (1992), or A. Muchielli et alii (1998).

15 All these types of frames are widely discussed by Coseriu in Determinación y entorno. Dos problemas de una linguistica del hablar (1955-1966: 45-54). 


\begin{tabular}{ll} 
SITUACIÓN & inmediata \\
mediata & \\
REGIÓN & zona \\
& ámbito \\
& ambiente \\
CONTEXTO & \multicolumn{1}{c}{ idiomático } \\
& verbal
\end{tabular}

\begin{tabular}{|c|c|}
\hline mediato & inmediato \\
\hline & \\
\hline & \\
\hline
\end{tabular}

extraverbal $\mathrm{f}$

físico

empírico

natural

práctico u ocasional

histórico

cultural

\begin{tabular}{|l|l|l} 
particular & \multicolumn{1}{l}{ universal } \\
& & $\begin{array}{l}\text { actual } \\
\text { pretérito }\end{array}$ \\
\hline & &
\end{tabular}

\section{UNIVERSO DE DISCURSO}

(Coseriu 1955-1956)

By situation Coseriu understands circumstances, spatial and temporal relations which are created because someone speaks in a certain moment and place (Coseriu 1955-1956: 46). The second type of frame is region, defined as "el espacio dentro de cuyos límites un signo functiona en determinados sistema de significación" (loc. cit.). The region is also concerned with the relation between a sign and our knowledge of the designated things. Here are taken into account, for instance, words from dialects which are used to offer local colour, technical words that evoke the area in which they are used as well. ${ }^{16}$ The following type of frame specified by Coseriu is the context of speech, understood as the reality which surrounds a sign, a verbal act or a discourse, as "knowledge" of the speakers, as physical presence and activity (op. cit., p. 48). The last type of frame is represented by the universe of the discourse, defined as "el sistema universal de significaciones al que pertenece un discurso (o un enunciado) y que determina su validez y su sentido" (op. cit., p. 51). In Orationis fundamenta. La preghiera come testo Coseriu delimits four universes of discourse, considering that four are the fundamental modes of human knowledge: a) the universe of current experience, b) the universe of science, c) the universe of fantasy and d) the universe of faith (Coseriu 2010: 8).

16 For a presentation in English of the surrounding fields, see http://www.romling.unituebingen.de/coseriu/detyenten.html. 
3.4.5.1. The following advertising text broadcasted on television is a relevant example for all the Coserian surrounding fields. ${ }^{17}$

(20) Demult, pe când oamenii străbăteau drumurile călare din zori și până-n noapte, un călător zăcea ostenit de zile și zile de drumeție. Gura îi era uscată, trupul plin de răni, iar sufletul amar. La o vreme, sfârșit de năduf, se prăbuși la poalele unor stânci. Acolo, în inima sălbăticiei, află un izvor cu apa limpede ca lacrima și curată ca aerul munților. De cum sorbi din el, rănile i se vindecară, iar sufletul își găsi alinarea. Izvorul minunilor i-a rămas numele, iar cu acest izvor, oamenii își mai potolesc și azi setea și patimile văzute și nevăzute. Izvorul Minunilor - Apă de legendă!

(Once upon a time, when people used to cross the roads on horseback from down until sunset, a traveller lied wearily because of too many days of wandering. His mouth was dry, his body full of wounds and his soul sad. At a time, he fell at the foothills, breathless. There, in the heart of wilderness, he found a crystal-clear and fresh mountain spring. Once he sipped of it his wounds healed and his soul found relief. Wonder Spring became its name, and nowadays, people still have been appeasing and quenching their seen and unseen passions. Wonder Spring - Legendary Water!)

3.4.5.2. First of all we can notice that a mythical world is proposed by displaying the story into the universe of the discourse of fantasy. This is possible because of the verbal context which is characterised by typical words and phrases for fairy tales, like "once upon a time", or archaic lexical forms (that tell us about the region they belong to). The extra verbal context becomes relevant as well by means of the displayed images, together with the voice behind them, on the one hand, and by means of a mysterious musical background, on the other hand. The images create a physical context (what the viewer can see), and the historical and cultural contexts are represented by the knowledge of the Romanian folklore. The real situation can be determined if we apply to relevance theory, taking into account that the advertising discourse is an ostensive-inferential communication (Wilson / Sperber 2004: 611). Here we should use the concept of reciprocal cognitive frame and that of obvious knowledge in connection with the speaker and the receiver of the message. The relation between the speaker and the receiver is not usually explicitly expressed. Every text has a real sender, even a written text or one presented by a narrative voice. This real sender endows the text with personality, with the help of what in Rhetoric is called ethos, the tonality which reveals an authority. For Dominique Maingueneau (2007: 118) the text is not intended to contemplation; it is an utterance "intended to a co-enunciator who must be made to adhere physically to the universe of sense." The power of persuasion of a discourse depends on whether it causes the recipient to identify with an entity endowed with certain social values. The quality of the ethos suggests the image of this "guarantor", who, by means of speaking, attributes himself an identity which fits with the world he represents within the enunciation. The paradox is that this guarantor has to legitimate his way of speaking within enunciation. Also, the fact that the authority of the speaker is manifested by means of the enunciation represents an argument for the idea that the utterances are dependent on the enunciation sourrounding fields. The reality of speaking

17 More examples for the surrounding fields taken from the advertising discourse can be found in Robu 2011b and Robu 2013. 
shows that we cannot separate the organization of the utterances by the circumstances of speaking. ${ }^{18}$

The interpretation of this example shows the utility of applying the coserian theory of the functional levels of speech to the public discourse. If we refer to the individual texts, we can see that they include all the three dimensions (universal, historical and individual) of speech, as Loureda (2010: 140-151) demonstrated. ${ }^{19}$ First, a text comprises universal aspects like speaker, listener and context. Secondly, from a historical dimension point of view, within a text, we can find forms of discourse tradition, or we can identify what is the importance of the repeated discourse. Thirdly, when the designation (from the universal level) and the meaning (specific for the historical level) unite, we can get to the sense an consequently to the finality of the particular texts, taking into account the illocutionary force, the perlocutionary and the ostensive-inferencial features of texts (especially of the advertising discourse). If we refer to example (20) we can say that its finality is to show the receiver the unique qualities of the mineral water (its magical property to cure your body and soul, as it happens in fairy tales) and to make the recipient wish to have it.

3.5. The Coserian text linguistics instruments offer the possibility to understand the complexity of texts/discourses, beyond the strict limits of the linguistic aspect. The sense of a text is expressed not only linguistically, but also extra-linguistically and this can be revealed by means of analysing the functions the sign gets within the discourse as speech activity. The advantage of the coserian framework is that it offers a broadview on speech, according to its three levels. It is important to note that this complex approach can meet some results from the nowadays tendencies in discourse analyses, as speech acts theory, or the theory of contexts, and that it can also integrate aspects from other new studies in language, as relevance theory (see supra 3.4.5.2.). The goal of integral text linguistics is to understand the modality of sense construction within texts, by exploring the functional levels of speech.

\section{References}

Adam, Jean-Michel (2008 [1999]): Lingvistica textuală. Introducere în analiza textuală a discursurilor. Traducere de Corina Iftimia, prefaţă de Rodica Nagy. Iaşi: Institutul European.

Aschenberg, Heidi (1998): „Probleme der philosophischen Übersetzung. Bemerkungen in Beziehung auf die deutschen Versionen von Sartres L'être et le néant", in: Archiv für das Studium der neueren Sprachen und Literaturen 150, 77-109 [in collaboration with Reinhold Aschenberg].

Borcilă, Mircea (2008): “Tra Blaga e Coseriu. Dalla metaforica del linguaggio a una poetica della cultura", in: Romania culturale oggi, N. Neşu \& L. Valmarin (eds.) Quaderni di Romania Orientale 2, Roma, Bagatto Libri, 253-271.

18 More than that, when we discuss the extra-verbal aspect, we have to take into account that all the other forms of communication relate to speech, whether it substitutes, emphasizes, repeats or contradicts it.

19 In this paper, Loureda completes Coseriu's model of speech levels, considering that the individual level manifest all the three dimensions of speech, as it can be seen in Table 2. 
Brune, François (1996 [1985]): Fericirea ca obligaţie. Psihologia şi sociologia publicităţii. Traducere din limba franceză şi prefaţă de Costin Popescu. Bucureşti: Editura Trei.

Coseriu, Eugenio (1955 - 1956): "Determinación y entorno. Dos problemas de una lingüistica del hablar", in: Romanistisches Jahrbuch, VII, 29-54.

Coseriu, Eugenio (1985): "Linguistic Competence. What is it Really?: The Presidential Address of the Modern Humanities Research Association", in: The Modern Language Review, vol. 80, part 4.

Coseriu, Eugeniu (1992): Competencia lingüística. Elementos de la teoría del hablar. Elaborado y editado por Heinrich Weber. Versión española de Francisco Meno Blanco. Madrid: Biblioteca Románica Hispánica, Editorial Gredos.

Coşeriu, Eugeniu (1997 [1958]): Sincronie, discronie şi istorie. Problema schimbării lingvistice. Ediţie în limba română de Nicolae Saramandu. Bucureşti: Editura Enciclopedică.

Coseriu, Eugenio (2007 [1980]): Lingüística del texto. Introducción a la hermenéutica del sentido. Edición, anotación y estudio previo de Óscar Loureda Lamas. Madrid: Arco/Libros S.L.

Coşeriu, Eugeniu (2009): Omul şi limbajul său. Studii de filozofie a limbajului, teorie a limbii şi lingvistică general. Antologie, argument şi note de Dorel Fînaru. Iaşi: Editura Universităţii „Alexandru Ioan Cuza”.

Coşeriu, Eugeniu (2010 [2000]): Rugăciunea ca text [Orationis fundamenta. La preghiera come testo]. Traducere de Andreea Grinea, in: Transilvania, XXXIX, nr. 9, septembrie, $1-12$.

Coseriu, Eugen (2011 [2003]): Istoria filozofiei limbajului de la începuturi până la Rousseau. Ediție nouă, augmentată de Jörn Albrecht, cu o remarcă preliminară de Jünger Trabant. Versiune românească și indice de Eugen Munteanu și Mădălina Ungureanu, București: Editura Humanitas.

Coseriu, Eugenio, Loureda Lamas (2006): Óscar Lenguaje y discurso. Ediciones Universidad de Navara, S.A.: Pamplona.

van Dijk, Teun (1992 [1977]): Text and Context. Explorations in the semantics and pragmatics of the discourse. London/New York: Longman.

Dumistrăcel, Stelian (2006a): Limbajul publicistic românesc din perspectiva stilurilor funcţionale. Iaşi: Editura Institutul European.

Dumistrăcel, Stelian (2006b): Discursul repetat în textul jurnalistic. Tentaţia instituirii comuniunii fatice prin mass-media, Iaşi, Editura Universităţii “Alexandru Ioan Cuza”.

Itkonen, Esa (2013): "On Explanation in Linguistics", article in the forum discussion of this issue: http://www.kabatek.de/energeia/E5discussion.

Kabatek, Johannes (2005): “Tradiciones discursivas y cambio lingüístico”, in: Lexis 29, 151177.

Koch, Peter (1997): „Diskurstraditionen. Zu ihrem sprachtheoretischen Status und ihrer Dynamik“, in: Barbara Frank, Thomas Haye and Doris Tophinke (eds.): Gattungen mittelalterlicher Schriftlichkeit (Script Oralia 99). Tübingen: Gunter Narr, 43-79.

Loureda Lamas, Óscar (2007): Entrevista con Óscar Loureda Lamas, por Eugenia Bojoga, in: Revista electrónica de estudios filológicos, número 14, diciembre. (http://www.um.es/tonosdigital/znum14/secciones/entrevistas-\%20loureda.htm).

Loureda Lamas, Óscar (2010): "Nuevas perspectivas para el análisis del texto: introducción a una lingüística del texto integral”, en: Revista de Investigación Lingüística, nr. 13, 127-154. 
Maingueneau, Dominique (2007 [1998]): Analiza textelor de comunicare. Traducere de Mariana Şovea. Cuvânt înainte de Oana Popârda. Iaşi: Institutul European.

Moeschler, Jaques/Reboul, Anne (1995): “Le dialogue n'est pas une catégorie naturelle scientifiquement pertinente", in: Cahiers de linguistique française, nr. 17. Université de Genève.

Mucchielli, Alex et alii (2006 [1998]): Teoria proceselor de comunicare. Traducere de Livia Iacob, Iași: Editura Institutului European.

Munteanu, Cristinel (2007): "Sinonimia frazeologică în limba română din perspectiva lingvisticii integrale”. Pitești: Editura Independența Economică.

Oesterreicher, Wulf (1997): "Zur Fundierung von Diskurstraditionen", in: Barbara Frank, Thomas Haye and Doris Tophinke (eds.), Gattungen mittelalterlicher Schriftlichkeit (Script Oralia 99). Tübingen: Gunter Narr, 19-41.

Robu, Adriana Maria (2010): "Discursul politic electoral ca tip de discurs publicitar", in: Anuar de lingvistică şi istorie literară. Tomul XLIX-L/2009-2010, 143-150.

Robu, Adriana Maria (2011a): "Discourse/Text from Text Linguistics Perspective", in: Communication interculturelle et littérature, 2(14)/2011, 291-299.

Robu, Adriana Maria (2011b): "Relația „cadru” pragmatic - univers semantic, cu referire la discursul publicitar", in: Anuar de lingvistică și istorie literară Tomul LI/2011, 347-360. Special number dedicated to Papers of Colocviul Internațional Aniversar „Eugeniu Coseriu - 90 de ani de la naștere".

Robu, Adriana Maria (2013): "Particularităţi pragmatice ale discursului publicitar românesc actual”, PhD Thesis defended at the University „Alexandru Ioan Cuza” Iași, Romania, September 2013.

Sperber, Dan / Wilson, Deirde (2009 [1986]): Relevance. Communication and cognition. Blackwell Publishing.

Tămâianu, Emma (2001): Fundamentele tipologiei textuale. O abordare în lumina lingvisticii integrale. Cluj: Editura Clusium.

Verschueren, Jef / Östman Jan - Ola (ed.) 2009: Key Notions for Pragmatics. Amsterdam/Philadelphia: John Benjamins Publishing Company.

Wilson, Deirde / Sperber, Dan (2010 [2004]): "Relevance Theory", in: L. R. Hord \& G. L. Ward (eds.). The Handbook of Pragmatics. Oxford. Blackwell, 607-632.

Sources:

http://crinantonescu.ro/Public/cat/16/Discursuri.html

www.antena3.ro

Most of Coseriu's publications can be downloaded at www.coseriu.de 